\title{
E-GOVERNMENT IMPLEMENTATION MODELS AND PRESENTING E- GOVERNMENT 2.0 CONCEPTUAL MODEL
}

\author{
Mansore Hosseini-Shoar ${ }^{1}$, Alireza Isfandyari-Moghaddam², Atefeh Zarei ${ }^{3}$, and Mohammad \\ Hassanzadeh $^{4}$ \\ ${ }^{1}$ Islamic Azad University, Hamedan Branch, Iran (Corresponding author), \\ ${ }^{2,3}$ Department of Knowledge and Information Science, Islamic Azad University, \\ Hamedan Branch, Iran. \\ ${ }^{4}$ Knowledge and Information Science Department, Faculty of Management and Economics, \\ Tarbiat Modares University, Tehran, Iran.
}

\begin{abstract}
The purpose of the present study is to determine and identify some essential components of E-Government, and kinds of E-Government implementation models, so that by using them, the E-Government can progress better in the way of fulfilling its goals. This research was done by using descriptive method, by reviewing the texts related to E-Government, and surveying the E-Government implementation models, social networks and web2.0 By assessing the EGovernment implementation models, the E-Government 2.0 model was presented. The finding of the study indicated that there are models for the implementation of E-Government 2.0. Regarding the function of web 2.0 technology and social networks in E-Government, as well as investigating the effective factors in accepting this technology, E-Government conceptual model is presented. The results reveal that by admission of web 2.0 technology and social networks into the E-Government, we witness the advent of E-Government 2.0. Before generating EGovernment 2.0, we may pay attention to the implementation models and choose the most appropriate one given the circumstance that the E-Government is rendered in it. Presenting E-Government 2.0 conceptual model in this regard is effective.
\end{abstract}

Keywords: E-Government, implementation models, web 2.0, social networks

\section{INTRODUCTION}

E-Government is a collection of electronic communications that occurs between Governments, organizations and citizens. Regarding E-Government, different aspects of accountability, transparency, efficiency, etc. are considered in different definitions (Lu, Zhou, and Wang (2009). According to Lupua (2015), one of the significant characteristics of EGovernment is that the government should be: small, moral-centre, responsible, auditable, and transparent; such that, the citizens will be aware of the measures and activities' progression trends. Also, one of the main characteristics of E-Government is that, instead of being an incharge government, it should be a ruler government, instead of a serving government; it should be an entrepreneur government, it should seek engagement and be interactive, active, available and inclusive (rendering services as $24 * 7$ ), and finally instead of being organization-centered, EGovernment should be serving-centered.

Nowadays, information and communication technology (ICT)affects the sovereignty structure of governments in both horizontal and vertical dimensions. In vertical dimension,ICT has decreased bureaucracy by reducing time and money, and developing official services. In the 
horizontal level, ICT affects the scope and the manner of government engagement in economic, social, cultural and political domains (Faghihi, 2014). Although E-Government includes the ICT utilization, E-Government2.0 the government's new approach to using web 2.0 devices. In fact, recent advances in electronic technologies and the penetration of these technologies in all sections of society, has caused the E-Government to use the web 2.0 technologies, which nominated as E-Government2.0. there are different models for E-Government implementation, and identifying the E-Government implement models has a significant importance because, it helps countries to have knowledge and select the most appropriate methods and ways to implement E-Government. The purpose of this article is to identify different types of EGovernment implementation, with a special focus on E-Government 2.0 and finally presents the conceptual model of E-Government2.0.

\section{PURPOSE OF THE STUDY}

Given the wide application of social networks by citizens, it is obvious and indispensible that E-Government also utilizessuch facilities and web 2.0. Since, to our knowledge, theEGovernment2.0 has not been investigated in Iran, this research has evaluated the E-Government 2.0, because, as the researcher believes, without presenting a conceptual modelof the usage of web 2.0 technology and social networks in E-Government, E-Government can have little progression and cannotor achieve its long-term and short-term E-Government 2.0 objectives. Accordingly, the purpose of this research is to determine and identify some E-Government implementation models based on their different definitions and conceptualizations in various texts; so as to present E-Government 2.0 conceptual model.

\section{RESEARCH QUESTIONS:}

What are the E-Government's different implementation models?

What is the E-Government's 2.0 implementation model?

\section{RESEARCH METHODOLOGY:}

This research was done by using descriptive method, by reviewing the texts related to EGovernment, and surveying the E-Government implementation models. First, by using internet, different websites and search engines, Government implementation models were searched. Among the diverse models, the best and the most important ones were selected, and they were evaluated, revised and collected. Then, web 2.0 technologies and social networks were assessed. The models having the most applications and utilizations were selected and their characteristics were specified. While searching in the web, and observing the application of web 2.0 devices in E-Government, the following criterions were considered:

1. evaluating devices having the most utilization

2. the selected web 2.0 devices should have application in government sectors (EGovernment)

Finally, by assessing the E-Government implementation model, and byreviewing the research associated withweb 2.0 and social networks, this research was carried out.

\section{REVIEW OF LITERATURE}

Much research has been done in E-Government implementation models domain, but we could find no research about E-Government in Iran. Here we refer to some studies carried out in E-Government 2.0 domain:

Boughzala, Janssen and Assar in a research titled as "case studies in E-Government 2.0: changing citizenship relations", aimed to present a comprehensive and multidimensional 
approach, and to survey and implement E-Government 2.0. It presents the collaboration of international panel of experts andthe implementation of different types of methodologies and case studies. It also analyses various technological perspectives inimplementingE-Government 2.0.

Sivarajah (2014) in a research titled as "investigating the use of web 2.0 technologies in EGovernment 2.0". asserts that E-Government 2.0 has undergone changes in terms of public services and management in the previous decade. Lately, second generation of web technologies (web 2.0) has been started in order to deliver E-Government services. However, it brings about more challenges. In comparison to traditional models of presenting information or traditional models of developing digital services, web 2.0is more interactive, and provides the ground for a new collection of interests, values and risks of those who useweb 2.0 as part of E-Government approach. Rudimentary levels of 2.0 web is used in E-Government, accordingly, this requires a research to investigate the use of web 2.0technologies in E-Government, and to offer practical recommendations to employees. This research was carried out so as to present a new conceptual model that can be employed in executing and assessing web 2.0, and then a conceptual model will be drawn.

Husin, Evans, and Deegan (2016) carried out a research titled as "having access to effective use of and acceptance of web 2.0 among the staff of state organizations of Australia. In this research, it is asserted that it is not easy to ensure that web 2.0 is used effectively in state organizations. The organizations should be aware of some issues while executing web 2.0, the aforesaid research, the presented conceptual model argues for the importance of management, technology and citizens, which affects the level of use of web 2.0. The purpose of the research is to identify and investigatethese issues in government context. The main finding of the above research is that a policy acts as a primary catalyzer in changing culture and effective use of web 2.0technologies in government contexts. It was also found that, developing cognition of senior managers to motive their staff to use internalweb 2.0 is important.Consequently, the suggested conceptual model can help the government organizations to develop the effective acceptance of web 2.0 technologies through identifying the motives of their staff, and to develop social networks appropriate organizational policies.

Bonsón,Torres, Royo,Flores (2012)in aresearch titled as "Local e-government 2.0: Social media and corporate transparency inmunicipalities" aimed to offer a general view about using web 2.0 and social networks in local governments of European Union. The study aimed to determine whether electronic participation increases in local governments by using this technology, and to specifythe factors promoting the developmental level of these devices at local scales. The results of the study indicated that, most of the local governments' use of web 2.0 and social media, to increase transparency is at rudimentary stage of development, and the conversation concept between the corporates and utilizing web 2.0promulgate electronic participation (at local scale) is not developed enough.

Khasawneh, \& Abu-Shanab (2013). In their research about the use of social media in Egovernment, confirm the positive effect of usingFacebookin E-government.

Sivarajah (2014) exploring the application of web 2.0 technologies in the context of egovernmentfrom organizational, technological and social perspectives.

Given this literature it can be said that the application of web 2.0 technologies has been considered by some governments and assume these technologies essential, and moving toward Egovernment and its promotion is the main principle of the majority of the countries. However, we could find no clear and comprehensive research that refer to all or most of the technologies' practical aspects in the government. 


\section{E-government 2.0}

The question why web 2.0 was selected for services of e-government, will be answered by assessing the features of web 2.0. The characteristics of web 2.0 technology are a reason for choosing web 2.0 devices in rendering electronic services in governments; because simplicity and ease of connection can be an important reason. Accepting technology and utilizing it by the users has a positive relationship with the simplicity and ease of use of technologies. It is assumed that the user's mentality about information technology, has a positive and significant effect on the attitude of the users about using ICT ().Soleimani and Zarafshani, 2011, Esmaili et.al., 2013, Moradi, Mehrani, Boromand, 2010). We can rely on the technology acceptance models which have been done in different domains, and consider web 2.0 characteristics a reason for its usage by the citizens. The characteristics of web 2.0 include: active participation and user's innovation andcollective wisdom. The content is the core, simplicity and rich experiences of the users.

Given that the application of e-government and using technology in government is indispensible, the successful acceptance of e-government is dependent on this issue. The success of e-government can be formulated by different criterions such as, time, money, quality (Atkinson, 1999), the satisfaction of interest group of e-government (Xu etal, 2010) and the fulfillment of functional and responsibility regulation (Joosten et al, 2011). Figure (1) has shown the features of e-government

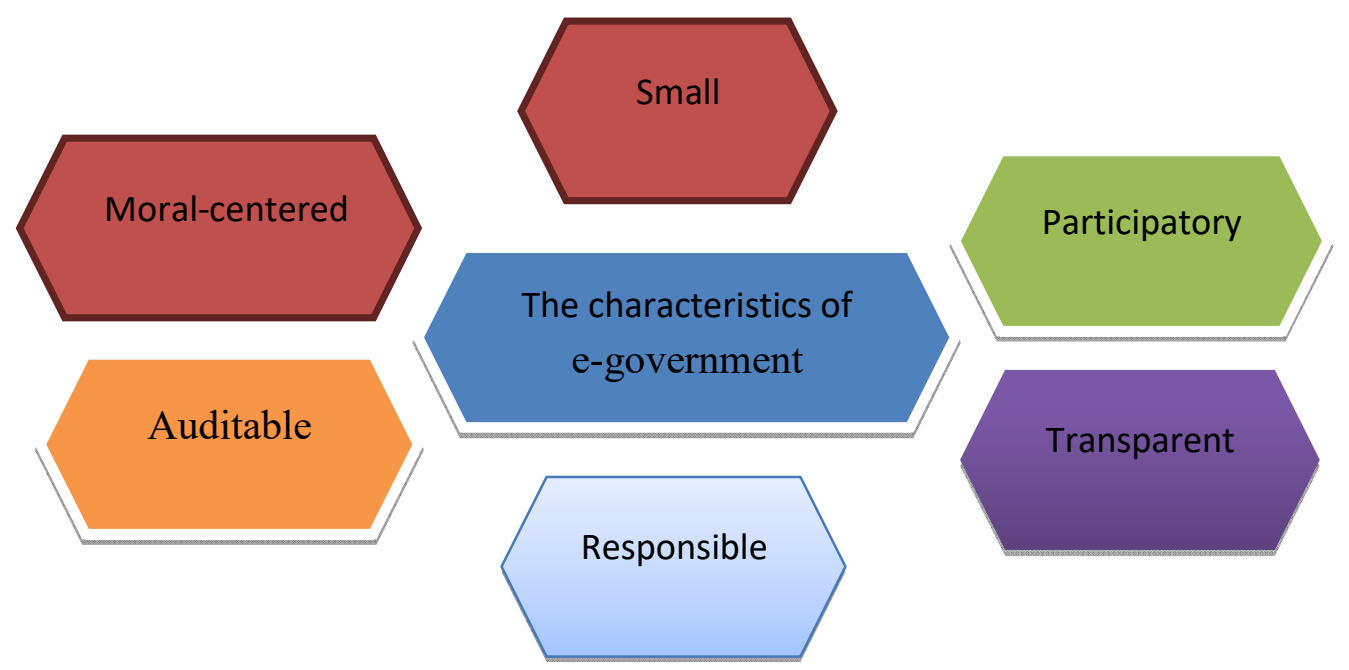

Figure (1) characteristics of e-government

\section{The main characteristics of e-government 2.0}

The benefits of applying web 2.0 in governments are numerous, and the devices and methods of web 2.0 can help to improve the policies, and offer services through enriching government interactions with foreign stockholders and strengths the management of internal knowledge. In fact, the application of web 2.0 in e-government can have positive effects. The characteristics of e-government include: society-centered, generating and developing content by the user, openness and transparency-which is the most essential part in e-government 2.0-and 
cooperation (Boughzala, Janssen, Assar, 2015). The characteristics of e-government 2.0 can be observed in figure (2).

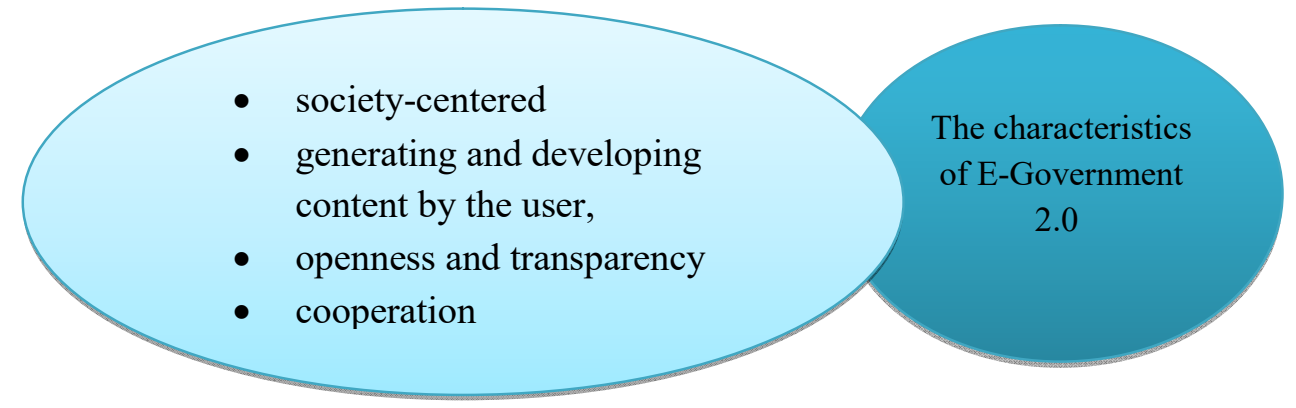

Figure (2). Characteristics of E-Government 2.0

\section{E-Government implementation models}

There are different models for the E-Government implementation, which are used in different domains while assessing the technologies acceptance.Although these models are different in terms of number of establishment stages, they have naturally common aspects that havehighlighted their homogeneity in E-Government implementation. In the following section technology acceptance models are presented.

\section{Technology Acceptance Model1 (ATM)}

In 1989, Davis offered Technology Acceptance Model (ATM). Perceived ease of use (PEOU) and perceived usefulness (PU) form the basis of this model. Researchers studying information systems, consider Technology Acceptance Model as an important theory and have done many investigations to put this theory into practice. Technology Acceptance Model is determined based on two major variables which include: perceived ease of use (PEOU) and perceived usefulness (PU)(Davis, Bagozzi, \& Warshaw, 1989).

2. Technology Acceptance Model2 (TAM2)

Having presented primary Technology Acceptance Model, Technology Acceptance Model2 (TAM2) evolved.

3. Technology Acceptance Model (TAM3)

The Technology Acceptance Model (TAM3) which was offered by Venkatesh and Balla in 2008, was formed based on extensive studies about Technology Acceptance Model. They combined 1- Extended Technology Acceptance Model2 (TAM2) with Determinants of Perceived Ease of Use and called it Technology Acceptance Model (TAM3) (Yaghoubi, Aboui Ardakan, Gouyandeh NajafAbadi, 2014: 15). Technology Acceptance Model (TAM3) was presented in association with information technology.

4. Theory of Reasoned Action (TRA) (logical action, 1975)

This theory was introduced by Fishbein \& Ajzen (1975)in their book entitled " Belief, attitudes, intention and behavior: An introduction to theory andresearch". It is based on the assumption that people behavior logically. In other words, the behavior of person is a positive function of his inclination to do that behavior. In addition, it seems that the behavioral inclination of a person is a linear function of two psychological variables: 1 . the person's attitude toward doing the behavior and 2. the mental criteria of the person regarding that behavior. Therefore, individuals collect all the available information about the target behavior and assess them deliberately. They also consider the effect and outcome of the actions. Then, based on their own reasoning, decide whether to do the behavior or avoid 
doing it (Pikkarainen, Pikkarainen, Karjaluoto, Pahnila, 2004: 226). Mental norms, people's attitude to the issue and behavioral intention are three factors that leads to actual behavior in a person.

\section{United Nations model}

In a study done in 2002 by the United Nations, a five-stage model was specified for implementing e-government. United Nations offered this model to determine the status of developmentof the countries and, at the same time, shows their preparation to accept information technology. The model focuses on the users and the type and number of presented services. Identifying each of these steps has been accomplished by surveying the e-government status in the United Nations member states how to develop it in the world. These step include: 1. Genesis (advent)2. Promotion 3. Interaction 4. Transaction 5. Integrity (Moghadasi, 2006: 34).

\section{LAYNE- LEE}

This model was introduced byKAREN LAYNE, professor of urbane affaires college, and JUNGWOO LEE, professor of business collage of University of Nevada Las Vegas, and is based on a series of organizational and technical management feasibilities, and based on the United States experiences. According to these researchers, in order to generate an Internetbased e-government and digital methods, the following steps are necessary: the first step is making a complete list (inventory), the second step is transaction, the third step is public integration, and the fourth step is horizontal integration (moghadasi, 2006).

7. Gartner model

This model was developed by Gartner group in 2002. In these models, there are three steps for the maturation of e-government: communicating information, interaction, exchange and transformation (Safari, et al, 2004).

8. Southeast Asia and Pacific model

In this model, Southeast Asia and Pacific e-government maturation stepsare in six stages as follows: 1. Launching E-mail system and intranet 2. facilitating public and inter-organization access to information 3 Enabling two-way communication 4. Empowering value exchange 5. Digital democracy 6. Integrated government (Hassangholipour, 2006).

9. Stages of information technology growthmodel Nolan

in 1979, Nolan introduced the stages of information technology growth in organizations in six stages. These six stages involve: 1. Elementary 2. Expanding and development 3. Control 4. Integration 5. Data management 6. Maturation (Safari etal., 2004).

\section{Misra \& Dhongra model}

Misra \& Dhongra suggested a model that has an organizational view toward e-government maturation. The emphasis of this model is on stages that organizations go through in the egovernment implementation. This model introduces six stages for -government maturation including: the first step: closed 2. Introductorystage 3. Scheduled stage 4. Fulfilled stage 5. Internalization 6. Optimization (Safari et. al, 2004).

11. Deloitte \& Touche counseling group model:

Deloitte \& Touche counseling groupand Deloitte \& Touche research team presented a model for e-government maturation in 2000. In this model, e-government maturation is considered as a six-stage continuum as follows: the first step, publishing/sharing the information; second step is formal two-way exchanges, third step is multi-functional portals, the fourth step is personalizing the portal, the fifth step is collecting shared services, and the sixth step is total integration and transforming/changing the institution. 


\section{Utah State model}

Given the requirements of Utah State of America, this model was designed which includes the following steps: simple website, punctual government, integrated government and changed government (Safari et,al., 2004).

\section{Unified theory of acceptance technology (utaut)}

The purpose of Unified theory of acceptance technology is to explain the intentions of the user in using IS and his behavior in subsequent uses. According to the theory, four key structures (expected performance, necessary effort, social influence and facilitating condition)are direct factors of intention and use behavior (Venkatesh et al., 2003). In fact, Venkatesh et al (2003) introduced Unified theory of acceptance technology and using technology. They added some components to the Technology Acceptance Modell of Davisany of these components had a significant effect on the behavioral intention and finally using the technology. This model is developed based on the other models of technology acceptance.

Venkatesh and Davis considered four important components in the acceptance and usage of technology, including: predicting performance, predicting effort, social influence and facilitating conditions. Table (1) shows the e-government implementation models.

Table 1. government implementation models

\begin{tabular}{|c|c|c|}
\hline Row & Model name & Stages of implementation \\
\hline 1 & $\begin{array}{c}\text { Technology } \\
\text { Acceptance Model1 }\end{array}$ & $\begin{array}{l}\text { 1. Perceive ease of use (PEOU) 2. Perceived usefulness (PU) } \\
\text { 3. Attitude toward utilization 4. Deciding to use 5. Use }\end{array}$ \\
\hline 2 & $\begin{array}{c}\text { Technology } \\
\text { Acceptance Model3 }\end{array}$ & $\begin{array}{c}\text { Is a combination of Technology Acceptance Model } 2 \text { and } \\
\text { determinants of perceived ease of use }\end{array}$ \\
\hline 3 & $\begin{array}{l}\text { Theory of Reasoned } \\
\text { Action(logical } \\
\text { action) }\end{array}$ & 1. Mental norms, 2. Attitude 3. behavioral intention \\
\hline 4 & United nations & $\begin{array}{c}\text { 1. Genesis (advent) 2. Promotion 3. Interaction } 4 . \\
\text { Transaction 5. Integrity }\end{array}$ \\
\hline 5 & LAYNE- LEE & $\begin{array}{l}\text { 1. making a complete list (inventory), 2. transaction, } 3 \text {. } \\
\text { public integration, } 4 \text {. horizontal integration }\end{array}$ \\
\hline 6 & Gartner group & $\begin{array}{l}\text { 1. communicating information,2. interaction, 3. exchange } 4 . \\
\text { transformation }\end{array}$ \\
\hline 7 & $\begin{array}{l}\text { Southeast Asia and } \\
\text { Pacific model }\end{array}$ & $\begin{array}{l}\text { 1. Launching E-mail system and intranet } 2 \text {. Facilitating public and } \\
\text { inter-organization access to information } 3 \text { Enabling two-way } \\
\text { communication } 4 \text {. Empowering value exchange 5. Digital } \\
\text { democracy } 6 \text {. Integrated government }\end{array}$ \\
\hline 8 & $\begin{array}{l}\text { stages of } \\
\text { information } \\
\text { technology } \\
\text { growthmodel Nolan }\end{array}$ & $\begin{array}{c}\text { 1. Elementary 2. Expanding and development 3. Control } 4 . \\
\text { Integration 5. Data management } 6 . \text { Maturation }\end{array}$ \\
\hline
\end{tabular}

9

\section{Misra \& Dhongra model}

Deloitte \& Touche 10
1. closed 2. Introductory stage 3. Scheduled stage 4. Fulfilled stage 5. Internalization 6. Optimization

publishing/sharing the information; second step is formal two-way exchanges, third step is multi-functional portals, the fourth step is personalizing the portal, the fifth step is collecting shared services, and the sixth step is total integration and transforming/changing the institution. 


\begin{tabular}{|c|c|c|}
\hline 11 & Utah State & $\begin{array}{c}\text { simple website, punctual government, integrated government } \\
\text { and changed government }\end{array}$ \\
\hline 12 & Ghasemzadeh-Safari & $\begin{array}{c}\text { Generating government threshold 2. Presence 3. Exchange } 4 . \\
\text { Interaction 5. Transformation }\end{array}$ \\
\hline 13 & $\begin{array}{l}\text { Unified theory of } \\
\text { acceptance } \\
\text { technology }\end{array}$ & $\begin{array}{c}\text { expected performance, necessary effort, social influence and } \\
\text { facilitating condition }\end{array}$ \\
\hline
\end{tabular}

\section{THE CONCEPTUAL MODEL OF THE RESEARCH}

By using web 2.0 technology and social networks in e-government, focusing on different aspects of e-government should go with factors that are influential in the e-government 2.0 implementation. By offering e-government 2.0 conceptual model-that modifies the potential hindering factorsand strengths aspects of positive factors- e-government 2.0 is formed. Also, offering conceptual model assists the designers and developers of e-government 2.0 implementation domain. As can be seen in the following picture, government, information technologies and web 2.0 create e-government 2.0 altogether, in which web 2.0 technology includes web 2.0 devices and social networks. There are some influential factors in rendering and implementation of e-government, 2.0, which are located in the sienories of social, economic, organizational, technological, cultural, individual-psychological and motivational factors.

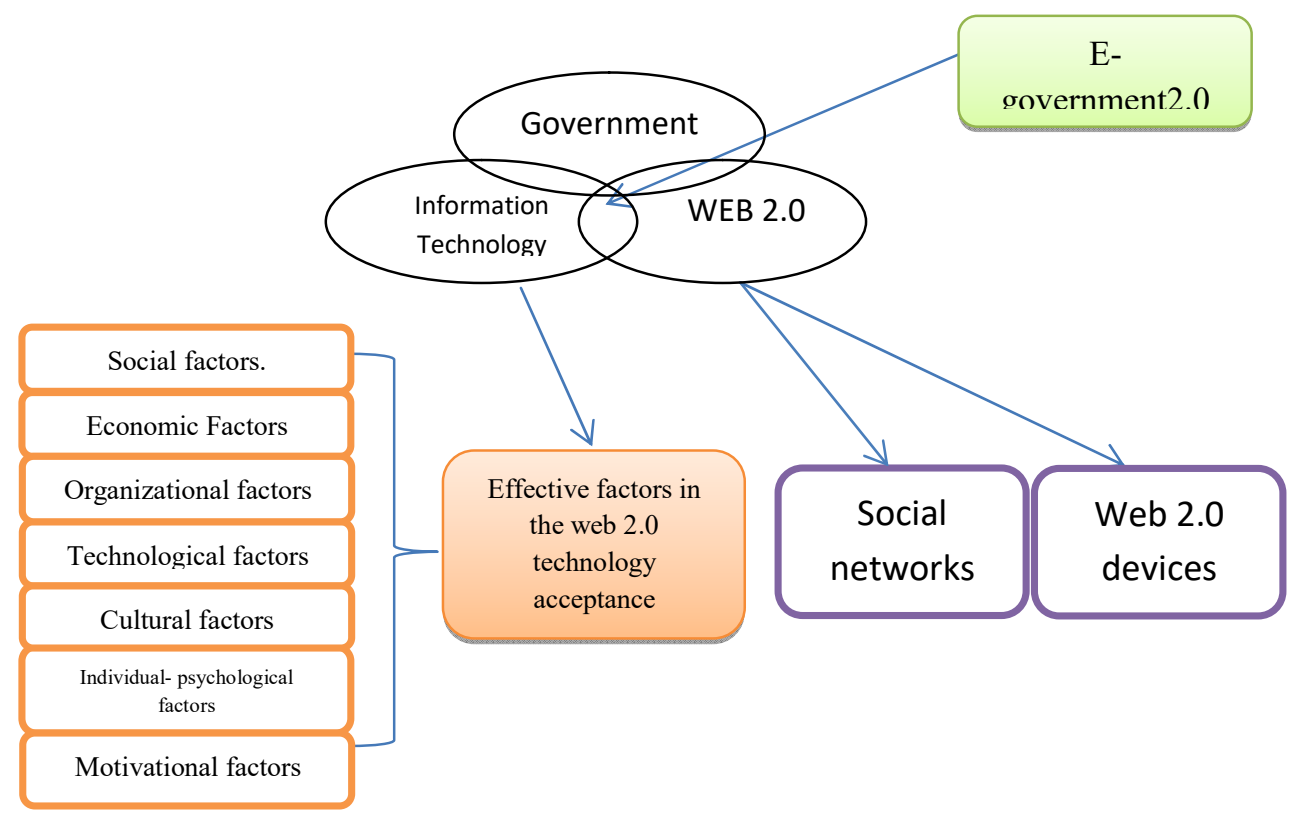

Figure (3) research conceptual model 


\section{CONCLUSION}

Today, we live in a world that communication and information technology has developed in almost all areas of human activities with an unprecedented speed. The rapid development of economic and knowledge are essential to increasing competition phenomenon in the future, this phenomenon along with globalization trend has been active for decades (Benzer, 2015). Egovernment implementation is the major issue for technologies usage in the governments. Egovernment 2.0 is created By injecting web 2.0 devices and social networks in the government. Before making e-government 2.0, we should pay attention to the implementation models and choose the most appropriate alternative, one that fits the existent condition of the e-government. Web 2.0 devices and social networks have lots of benefits andpeculiaritiesthat result in their usefulness in the governments. However, there are many factors that are influential in the acceptance of web 2.0 technologies and social networks in the e-governments and they must be considered attentively. As can be ssen in figure (3) the e-government 2.0 conceptual model is drawn. In this model, e-government 2.0 is formed by entering web 2.0 technologies and social networks. Some factors are effective in the acceptance of this technology.

\section{REFERENCES}

Atkinson, R. (1999). "Project management: cost, time and quality, two best guesses and a phenomenon, its time to accept other success criteria." International Journal of Project Management, 17(6): 337-342.

Benzer, Recep (2015). "E-Government in Developed Countries, The Case of Turkey (IJCSIT)". International Journal of Computer Science and Information Technologies. Vol. 6 (1), P. 710-714.

Bonsón, E. Torres, L. Royo, S. Flores, F. (2012) "Local e-government 2.0: Social media and corporate transparency inmunicipalities".Government Information Quarterly, Vol 29, Iss 2, P. 123-132 .

Boughzala, I., Janssen, M., Assar, . S. (2015)." Case Studies in e-Government 2.0Changing Citizen Relationships". Springer Cham Heidelberg New York Dordrecht London - ISBN 978-3-319-08080-2 ISBN 978-3-319-08081-9 (eBook).

Davis, F.D.; Bagozzi, R.P.\& Warshaw, P.R. (1989). "User acceptance of computer technology: $A$ comparison of two theoretical models". Management Science. Vol. 35, No. 8, P. 982 1003.

Faghihi, M (2014). E-government as social-technical system: categorizing implementation models", technology and science politics, No. 4

Hassangholipour Yasori, M (2015). An introduction to informational systems with e-government approach (concepts and applications). The first national congress about development and innovation in human sciences, Shiraz, Kharazmi sciences and technology higher education institute

Husin, M.H.; Evans, N. \& Deegan, G. (2016). 'Achieving adoption and effective usage of web 2.0 among employees within Australian government organizations', Journal of Systems and Information Technology. Vol. 18, No, 1, P. 41-63.

Ismaili,M; Toloui Ashlaghi, A; Pourebrahimi A.R.; and Isamaili, R. (2013) investigating the level of information technology acceptance and implementation among the staffs od Shahid Beheshti medical sciences university, based on Davis model. Pazhouhande, No.1, pp: $40-45$ 
Janssen, M., \& Estevez, E. (2013). Lean government and platform-based governance: Doing morewith less. Government Information Quarterly, 30(1), S1-S8.

Khasawneh, Rawan T. \& Emad A. Abu-Shanab (2013). "E-government and social media sites: The role and impact." World Journal of Computer Application and Technology. P. 1, No. 1, P. 10-17.

Lu, Y., Zhou, T., and Wang, B., (2009), Exploring Chinese Users' Acceptance ofInstant Messaging using the theory of planned behavior, the TechnologyAcceptance Model, and the Flow Theory", Computers in Human Behavior, 25,29-39.

Lupua, Corina (2015). "The role of ICT in the development of e-government". 'SILVAE GENETICA. Vol.57,No.1 Available online May 2015 www.sauerlander-verlag.com.

Moghdasi, A.R (2005). E-government implementation model. Tadbir. No. 160: 33-37

Moradi, M; Mehrani K.; Broumand, M. (2010)investigating the effective factors on the acceptance of information technology by police forces, quarterly police human development, 7 th year, No. 28

Pikkarainen T.; Pikkarainen K.; Karjaluoto, H. \& Pahnila S. (2004)."Consumer acceptance of online banking:An extension of the technology acceptance model". Internet Research. Vol. 14, No. 3, P. 224-235.

Safari, H.; Khoshsima, GH.; Mohammadian, A; Moslehi, A; Haki, K.; Farazmand. E.; and Tamizi, A.R. (2002) e-government maturation model, Iran commercial department, management knowledge. No. 63, pp: 53-78

Sivarajah, U.(2014)."Exploring the application of web 2.0 technologies in the context of egovernment" (PhD Thesis), Brunel University London.

Soleimani, A; Zarafshan K (2011) the effective factors on accepting information technology by students of agricultur هنرستانهاى of Kermanshah Province, by using technology acceptance model". Information technology and sciences, No. 4 (successive 66)

Venkatesh, V.; Morris, MG, Davis, GB \& Davis, FD (2003), 'User acceptance of Information Technology: toward a unified view'. MIS Quarterly. Vol. 27, No. 3, P. 425-478.

$\mathrm{Xu}, \mathrm{X}$., Zhang W., and Barkhi, R., 2010. IT infrastructure capabilities and IT project success: a de velopment team perspective. Information Technology and Management, 11(3), pp. 123-142.

Yaghobi, T.; Aboui Ardakan M., Gouyanday Najafabadi F. (2014) "investigating the effective factors on the web 2.0 technology acceptance from the perspective of highschool teachers based on the technology acceptance model. Education technology. Volume 9, No. 1: 11-24. 